\title{
Membudayakan Komunikasi Antar Budaya Dalam Aktivitas di Perkantoran
}

\author{
Oleh: \\ Siti Umi Khayatun Mardiyah \\ FISE UNY
}

\section{Abstrak}

Komunikasi antarbudaya merupakan komunikasi biasa layaknya komunikasi yang sering kita lakukan, hanya orang-orang yang terlibat mempuyai latar belakang budaya yang berbeda. Komunikasi kita dengan orang lain khususnya dalam aktivitas di perkantoran berpotensi mengandung komunikasi antar budaya, karena setiap orang selalu memiliki "budaya" yang berbeda-beda meskipun perbedaan itu hanya kecil.

Komunikasi antarbudaya mengkaji bagaimana budaya berpengaruh terhadap aktivitas komunikasi. Aktivitas komunikasi meliputi: apa makna pesan verbal dan nonverbal menurut budaya-budaya yang bersangkutan, apa yang layak dikomunikasikan, bagaimana cara mengkomunikasikannya (verbal dan nonverbal), dan kapan mengkomunikasikannya.

Membudayakan komunikasi antarbudaya memiliki keuntungan secara pribadi yaitu: 1) Perasaan senang dan puas dalam menentukan sesuatu yang baru, dalam hal ini kebudayaan orang lain yang belum pernah diketahui atau disadari sebelumnya; 2) Pengetahuan tentang komunikasi antarbudaya dapat membantu untuk menghindari masalah komunikasi. Pemahaman mengenai faktor-faktor yang melatarbekangi persepsi seseorang atau sekelompok orang dapar menjadi pedoman untuk memperlakukan mereka, sehingga tidak terjadi kesalahpahaman; 3) Kesempatan-kesempatan kerja banyak terbuka untuk bidang komunikasi antarbudaya; 4) Memberikan kesempatan untuk mampu mempersepsikan dan memahami diri sendiri. Usaha untuk mengerti kebudayaan orang lain dapat membuat pengertian yang lebih rasional tentang diri sendiri dan kebudayaan kita sendiri.

Kata kunci : Komunikasi, budaya

\section{Pendahuluan}

Kodrat manusia sebagai makhluk sosial tidak dapat menafikkan ke- butuhunnya untuk berkomunikasi dengan orang lain. Tidak dapat dipungkiri, tiapkali kita 
berkomunikasi dengan orang yang berbeda agama, tingkat pendidikan, status sosial, dan perbedaanperbedaan yang lain. Komunikasi yang terjadi antara orang-orang yang berbeda ras, bahasa, agama, tingkat pendidikan, status sosial atau bahkan jenis kelamin disebut sebagai komunikasi antar budaya. Kalau kita perhatikan, komunikasi kita dengan orang lain khususnya dalam aktivitas di perkantoran sangat berpotensi mengandung komunikasi antar budaya, karena setiap orang selalu memiliki "budaya" yang berbeda-beda meskipun perbedaan itu hanya kecil.

Komunikasi dan budaya mempunyai hubungan timbal balik. Deddy Mulyana dan Jalaluddin Rakhmat (2005) mengatakan bahwa budaya menjadi bagian dari perilaku komunikasi dan pada gilirannya komunikasi turut menentukan, memelihara, mengembangkan atau mewariskan budaya. Bagaimana seseorang berkomunikasi akan sangat bergantung pada budaya yang melekat pada-nya. Akan tetapi pada praktiknya, komunikasi yang terjadi diantara orang-orang yang berbeda budaya sering mengalami hambatan. Perbedaan ekspektasi dalam komuni-kasi sekurang-kurangnya menye-babkan komunikasi tidak lancar, pe-rasaan tidak nyaman atau kesalah-pahaman. Problem utamanya yaitu bahwa orang cenderung meng-anggap budayanya sebagai suatu kemestian dan menggunakannya sebagai standar untuk mengukur budaya lain. Jika hal itu terjadi dalam aktivitas di perkantoran maka orang tersebut akan terjebak dalam etnosentrisme yaitu memandang segala sesuatu dalam kelompok sendiri sebagai pusat segala sesuatu itu, dan halhal lainnya diukur dan dinilai berdasarkan rujukan kelompoknya.

Perbedaan budaya yang dapat menimbulkan hambatan dalam berkomunikasi di perkantoran berupa kesalahpahaman antar budaya dapat diminimalisir dengan cara mengetahui bahasa dan perilaku budaya orang lain/rekan kerja. Disamping itu perlu juga untuk mengetahui prinsip-prinsip komunikasi antar budaya dan mempraktikkannya dalam berkomunikasi dengan rekan kerja di kantor.

$$
\text { Mengenai komunikasi }
$$
antarbudaya tersebut, Chirzin dalam usulan yang disampaikan pada sidang UNESCO di Jenewa bulan Oktober 1994 menyampaikan: pertama, pendidikan seyogyanya mengembangkan kemampuan untuk mengakui dan menerima nilai-nilai yang ada dalam kebhinekaan pribadi, jenis kelamin, masyarakat dan budaya serta mengembangkan kemampuan untuk berkomunikasi, berbagi dan bekerja sama dengan yang lain. Kedua, pendidikan seyogyanya menumbuhkan perasaan solidaritas dan kesamaan pada tatanan nasional dan internasional, dalam. 


\section{$\$$}

perspektif pembangunan. Diharapkan melalui pendidikan itulah dapat ditumbuhkan kepekaan seseorang terhadap komunikasi antarbudaya.

Komunikasi antarbudaya terjadi bila komunikator atau orang yang mengirimkan pesan adalah anggota suatu kelompok budaya sedangkan penerima pesan atau komunikan merupakan anggota kelompok budaya yang berbeda. Setiap orang memiliki potensi perbedaan budaya dengan orang lain, sehingga budaya, komunikasi, dan komunikasi antarbudaya adalah kemestian.

\section{Komunikasi}

Hampir setiap orang membutuhkan hubungan sosial untuk berinteraksi dengan orang lain. Kebutuhan tersebut akan terpenuhi dengan berkomunikasi. Dengan komunikasi orang dapat mengekspresikan dirinya melalui pesan kepada orang lain. Komunikasi menurut Suranto (2005: ) secara sederhana didefinisikan sebagai proses penyampaian pesan/informasi dari komunikator kepada komunikan.

Komunikasi terjadi jika orang memberi makna terhadap pesan meskipun pengirim pesan tersebut tidak mengharapkan bahwa tindakannya dimaksudkan sebagai ba-gian dari peristiwa komunikasi. Da-lam konteks komunikasi antarbuda-ya, komunikasi lebih tepat di de-finisikan sebagai konsep yang hu-manistik (dua-arah, transaksional, interaksional) alih-alih konsep yang satu arah (linier), mekanistik (komunikasi sebagai transmisi), atau sekedar interaksi yang ditandai dengan adanya stimulus-respons (Deddy Mulyana, 2004 : 5).

\section{Budaya}

Berbicara masalah komunikasi tidak dapat terlepas dari adanya budaya. Hubungan antara budaya dan komunikasi adalah timbal balik. Budaya tak akan eksis tanpa komunikasi dan begitu juga sebaliknya ko-munikasi tidak akan eksis tanpa bu-daya. Geert Hofstede dalam Deddy Mulyana (2004: 14) mendefinisikan budaya sebagai pemrograman kolektif atas pikiran yang membedakan ang-gotaanggota suatu kategori orang dengan kategori lainnya. Budaya ter-diri dari berbagai tingkat yang masing-masing merepresentasikan lapisan pemrograman mental yang berlainan yaitu:

1. Tingkat nasional" menurut negara seseorang (atau negara-negara bagi orang-orang yang berimigrasi selama hidup mereka).

2. Tingkat regional dan/atau etnik dan/atau agama dan/atau afiliasi kebahasaan, karena kebanyakan negara terdiri dari berbagai kawasan yang berbeda secara budaya atau berbagai etnik dan/atau agama dan/ atau kelompok bahasa. 
3. Tingkat gender, berdasarkan apakah seseorang lahir sebagai perempuan atau lelaki.

4. Tingkat generasi, yang memisahkan kakek nenek dan orang tua dari anak-anak.

5. Tingkat kelas sosial, yang dikaitkan dengan peluang pendidikan dengan pekeriaan atau profesi seseorang.

6. Tingkat organisasi atau korporat bagi mereka yang bekrja, berdasarkan cara para pegawai tersosialisasikan dalam organisasi kerja mereka.

Tingkat-tingkat tersebut dapat ditambah atau dikurangi. Sebagian entitas budaya ini mungkin penting bagi sekelompok orang tetapi tidak penting bagi kelompok yang lain.

Budaya $\mathrm{m}$ memiliki ciri-ciri sebagai berikut:

1. Budaya bukan bawaan, tetapi dipelajari.

2. Budaya dapat disampaikan dari orang ke orang, dari kelompok ke kelompok. Dan dari generasi ke generasi.

3. Budaya berdasarkan sim-bol.

4. Budaya bersifat dinamis, suatu sistem yang terus berubah sepanjang waktu.

5.Budaya bersifat selektif, merepresentasikan pola-pola peri-laku pengalaman manusia yang jumlahnya terbatas.

6. Berbagai unsur budaya saling berkaitan.
7.Etnosentrik (menganggap budaya sendiri sebagai yang terbaik atau standar untuk menilai budaya lain).

\section{Komunikasi antarbudaya}

Secara sederhana, Gerhard Maletzke mendefinisikan komunikasi antarbudaya sebagai komunikasi antara manusia berbeda budayanya (Alex. H. Rumandor dkk. $2004: 1.17)$. Lebih lanjut dikatakan bahwa komunikasi antarbudaya merupakan komunikasi biasa saja, hanya orang-orang yang terlibat 'di dalamnya mempuyai latar belakang budaya yang berbeda. Sedangkan menurut Steward L. Tubbs dan Syivia Moss dalam Deddy Mulyana (2004: xi) meriyebutkan bahwa komunikasi antarbudaya adalah proses pertukaran pikiran dan makna antara orang-orang berbeda budaya. Komunikasi antarbudaya meliputi pemaknaan atas simbol dan sekaligus juga indeks oleh karena dampak praktik komunikasi kedua jenis tanda tersebut ketika ditampilkan oleh manusia, sering saling melengkapi.

Komunikasi antarbudaya pada dasarnya mengkaji bagaimana budaya berpengaruh terhadap aktivitas komunikasi. Aktivitas komunikasi tersebut meliputi: apa makna pesan verbal dan nonverbal menurut budaya-budaya yang bersangkutan, apa yang layak dikomunikasikan, bagaimana cara meng- 
komunikasikannya (velbal dan nonverbal), kapan mengkomunikasikannya. Komunikasi antarbudaya memiliki tiga dimensi yaitu:

1. Tingkat masyarakat kelompok budaya dari para pêlaku komunikasi.

2. Konteks sosial tempat terjadinya komunikasi antarbudaya.

3. Saluran komunikasi yang dilalui oleh pesan-pesan komunikasi sosialbudaya, baik yang bersifat verbal maupun nonverbal.

Pentingnya Membudayakan Komunikasi Antarbudaya dalam Aktivitas di Perkantoran

Proses komunikasi antarbudaya oleh Alex $H$. Rumandor dkk disebutkan sebagai berikut:

1.Meningkatkan pengetahuan kita tentang diri kita sendiri dengan menjelaskan sebagian dari perila-kuperilaku komunikatif yang tidak kita sadari.

2.Menjelaskan kendala-kendala terhadap pemahaman atas proses lintas budaya yang selama ini hampir tak teratasi.

Dalam proses komunikasi tersebut, dapat dicermati bahwa komunikasi tidak hanya meliputi katakata tetapi juga perilaku lain yang mendasari peristiwa yang sedang terjadi dan yang sudah terjadi pada masa lalu. Bagi seorang individu berkomunikasi dengan individu lain memerlukan pengetahuan tentang latar belakang budayanya. Bebera-pa syarat yang diperlukan individu untuk melakukan komunikasi antarbudaya secara efektif yaitu:

1.Adanya sikap menghormati angota budaya lain sebagai manusia.

2. Adanya sikap menghormati budaya lain sebagaimana adanya dan bukan sebagaimana yang kita kehendaki.

3. Adanya sikap menghormati hak anggota budaya yang lain untuk bertindak berbeda dari cara kita bertindak.

4. Komunikator lintas budaya yang kompeten harus belajar menye-nangi hidup bersama orang dari bu-daya yang lain.

Membudayakan komunikasi an-tarbudaya bagi individu memiliki ke-untungan secara pribadi antara lain:

1. Perasaan senang dan puas da-lam menentukan sesuatu yang baru, dalam hal ini kebudayaan orang lain yang belum pernah diketahui atau disadari sebelumnya.

2. Pengetahuan tentang komunikasi antarbudaya dapat membantu untuk menghindari masalah komunikasi. Pemahaman mengenai faktor-faktor yang melatarbekangi persepsi seseorang atau sekelompok orang dapat menjadi pedoman untuk memperlakukan mereka, sehingga tidak terjadi kesalahpahaman. 
3. Kesempatan-kesempatan kerja banyak terbuka untuk bidang komunikasi antarbudaya.

4. Memberikan kesempatan untuk mampu mempersepsikan dan memahami diri sendiri. Usaha untuk mengerti kebudayaan orang lain dapat membuat pengertian yang lebih rasional tentang diri sendiri dan kebudayaan kita sendiri.

Secara pribadi, individu harus memahami dan mampu beradaptasi dengan komunikasi antarbudaya khususnya di lingkungan kerja (kantor) yang beranggotakan orang-orang dengan berbagai latar belakang budaya. Karena bila tidak maka seseorang akan mengalami gegar budaya (culture shock). Gegar budaya merupakan suatu penyakit yang biasanya berhubungan dengan pekerja-an atau jabatan dan diderita oleh orangorang yang secara tiba-tiba berpindah atau dipindahkan ke luar negeri. Hal ini disebabkan oleh kecemasan yang disebabkan oleh hilangnya tandatanda dan lambang-lambang dalam pergaulan sosial.

Dengan memahami komunikasi antar budaya, tiap individu akan dapat bekerjasama dengan orang lain/rekan kerja di kantor tanpa mengalami gegar budaya.' Individu dapat mengoptimalkan potensi yang dimiliki tanpa disertai kecemasan akan hilangnya tanda-tanda dan lambang-lambang dalam pergaulan sosialnya di kantor.

\section{Daftar Pustaka}

Deddy Mulyana. 2004. Komunikasi Efektif Suatu Pendekatan Lintasbudaya. Bandung: PT Remaja Rosdakarya Offset.

Deddy Mulyana dan Jalaluddin Rakhmat. 2005. Komunikasi Antarbudaya Panduan Berkomunikasi dengan Orang-orang Berbeda Budaya. Bandung: PT Remaja Rosdakarya Offset.

Suranto AW. 2005. Komunikasi Perkantoran Prinsip Komuniksi untuk Meningkatkan Kinerja Perkantoran. Yogyakarta: Media Wacana.

Alex H. Rumandor, dkk. 2004. Materi Pokok Komunikasi Antarbudaya; 1-9; SKOM $4318 / 3$ SKS. Jakarta: Universitas Terbuka.

\section{Biodata Penulis}

Siti Umi Khayatun Mardiyah adalah salah satu staf pengajar pada jurusan pendidikan administrasi Fakultas Ilmu Sosial dan Ekonomi Universitas Negeri Yogyakarta 